\title{
Rapid retreat, acceleration and thinning of Glaciar Upsala, Southern Patagonia Icefield, initiated in 2008
}

\author{
Daiki SAKAKIBARA, ${ }^{1,2}$ Shin SUGIYAMA, ${ }^{2}$ Takanobu SAWAGAKI, ${ }^{3}$ \\ Sebastián MARINSEK, ${ }^{4}$ Pedro SKVARCA ${ }^{4}$ \\ ${ }^{1}$ Graduate School of Environmental Science, Hokkaido University, Sapporo, Japan \\ E-mail: sakakibara@pop.lowtem.hokudai.ac.jp \\ ${ }^{2}$ Institute of Low Temperature Science, Hokkaido University, Sapporo, Japan \\ ${ }^{3}$ Faculty of Environmental Earth Science, Hokkaido University, Sapporo, Japan \\ ${ }^{4}$ Instituto Antártico Argentino, Buenos Aires, Argentina
}

\begin{abstract}
The Patagonia Icefields are characterized by a large number of outlet glaciers calving into lakes and the ocean. In contrast to the recent intensive research activities on tidewater glaciers in other regions, very few observations have been made on calving glaciers in Patagonia. We analysed satellite images of Glaciar Upsala, the third largest freshwater calving glacier in the Southern Patagonia Icefield, to investigate changes in its front position, ice velocity and surface elevation from 2000 to 2011 . Our analyses revealed a clear transition from a relatively stable phase to a rapidly retreating and fast-flowing condition in 2008 . The glacier front receded by $2.9 \mathrm{~km}$, and the ice velocity increased by $20-50 \%$, over the 2008-11 period. We also found that the ice surface lowered at a rate of up to $39 \mathrm{~m} \mathrm{a}^{-1}$ from 2006 to 2010. This magnitude and the rate of changes in the glacier front position, ice velocity and surface elevation are greater than previously reported for Glaciar Upsala, and comparable to recent observations of large tidewater glaciers in Greenland. Our data illustrate details of a rapidly retreating calving glacier in Patagonia that have been scarcely reported despite their importance to the mass budget of the Patagonia Icefields.
\end{abstract}

\section{INTRODUCTION}

The Northern and Southern Patagonia Icefields cover areas of $3950 \mathrm{~km}^{2}$ (Rivera and others, 2007) and $12550 \mathrm{~km}^{2}$ (Skvarca and others, 2010), respectively, forming the largest temperate ice mass in the Southern Hemisphere. Recent studies report a significant mass loss of both icefields. Their contribution to global sea-level rise (SLR) was estimated to be $+0.105 \pm 0.011 \mathrm{~mm} \mathrm{a}^{-1}$ from 1995 to 2000 (Rignot and others, 2003) and $+0.067 \pm 0.004 \mathrm{~mm} \mathrm{a}^{-1}$ from 2000 to 2012 (Willis and others, 2012) from surface elevation changes. Results from the Gravity Recovery and Climate Experiment (GRACE) also revealed a significant contribution to SLR (Chen and others, 2007; Jacob and others, 2012). There are 17 outlet glaciers terminating in the ocean on the western side, and 35 outlet glaciers terminating in lakes mainly on the eastern side (Rignot and others, 2003). Ice discharge through these calving glaciers plays a key role in the ice mass budget. In contrast to the recent intensive research activities focusing on drastic changes in calving glaciers in Alaska, Greenland and Antarctica (e.g. O'Neel and others, 2005; Howat and others, 2008; Pritchard and others, 2009), only a few reliable observations have been carried out in Patagonia. This leaves considerable uncertainty concerning the future contribution of the Patagonia Icefields to sea-level rise. Observations of the front positions, ice thickness and flow velocities of calving glaciers in the Patagonia Icefields are instrumental in improving our understanding of the current status and future evolution of the Patagonia Icefields. It is necessary to increase the observational data on calving glaciers in terms of their front positions, ice thickness and ice flow velocity.

Several processes have been proposed as possible drivers of the rapid changes of calving glaciers observed in
Greenland, Alaska and other regions. The first hypothesis starts with changes occurring at the terminus (e.g. retreat, thinning, disintegration of floating tongues, trigger reduction in along-flow resistive stresses) (Joughin and others, 2004; Thomas, 2004; Howat and others, 2005). An imbalanced stress regime then leads to faster ice flow, thinning and steepening in surface slope that propagate rapidly upstream, resulting in further retreat of the glacier. Such a change in the stress regime may be controlled by basal overdeepening in a fjord (Howat and others, 2007; Nick and others, 2009). Another important process is meltwater input to the glacier bed, which potentially changes glacier dynamics as elevated subglacial water pressure enhances basal ice motion (e.g. Iken and Bindschadler, 1986; Iken and Truffer, 1997; Sugiyama and others, 2011). The amount of meltwater increases under warming climate conditions, potentially resulting in glacier acceleration, thinning and retreat (Zwally and others, 2002; Parizek and Alley, 2004). Water surface conditions in front of a calving glacier also play a role. A likely interpretation of seasonal frontal variations observed at Greenland tidewater glaciers is the presence and disappearance of ice melange covering the ocean, which is controlled by sea surface temperature. (Joughin and others, 2008; Amundson and others, 2010; Howat and others, 2010). These hypotheses proposed in previous studies are useful in interpreting the drivers of rapid changes in tidewater glaciers. For example, the retreat of many calving glaciers along the Greenland coast in 2002 and 2003 can be understood as a result of climatic and/or ocean forcing rather than the influences of surface and basal geometries (e.g. Howat and others, 2010). Nevertheless, only a few studies have been carried out on freshwater calving glaciers so far, despite the fact that many of these have also undergone rapid retreat. 

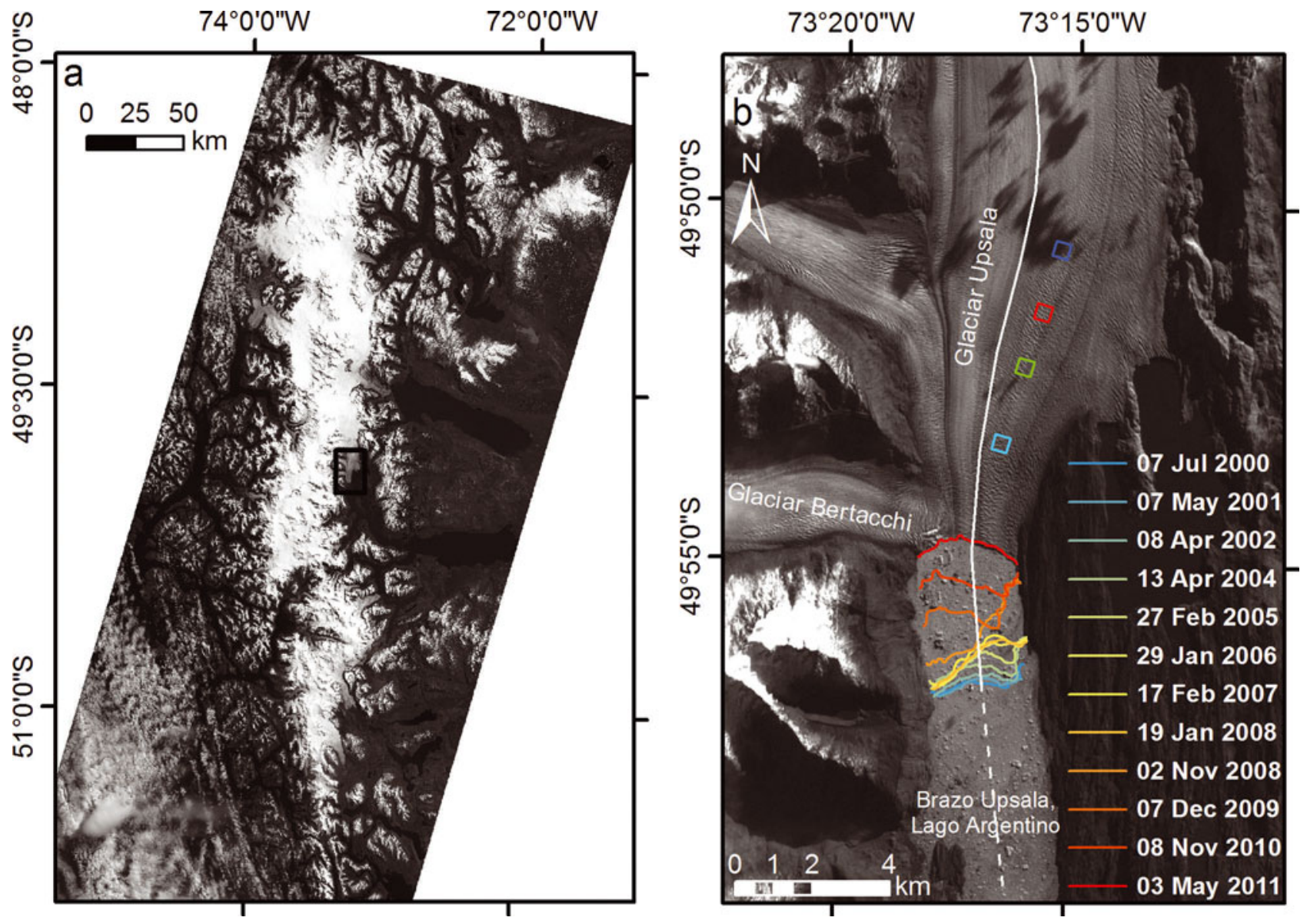

Fig. 1. (a) Landsat 7 ETM+ band 8 mosaic image of Southern Patagonia Icefield acquired on 14 October 2001. Study area is indicated by the box. (b) Frontal margins of Glaciar Upsala as observed from 7 July 2000 to 3 May 2011. Background is a Landsat 7 ETM+ band 1 image acquired on 3 May 2011. Boxes indicate ice velocity measurement sites. Surface elevation shown in Figure 6 was evaluated along the white line.

To study recent changes in a large calving glacier in Patagonia, we measured the front positions, surface elevation and ice velocity of Glaciar Upsala, one of the largest glaciers in the Southern Patagonia Icefield, using satellite images taken from 2000 to 2011. The migration of the frontal margin was tracked at 97-272 day intervals. The surface elevation change was obtained by comparing highresolution digital elevation models (DEMs) derived from stereographic satellite image pairs. This paper reports recent rapid retreat, thinning and acceleration revealed by these analyses, and discusses the role of glacier dynamics in the observed drastic recession of Glaciar Upsala.

\section{STUDY SITE}

Glaciar Upsala is located on the eastern side of the Southern Patagonia Icefield and is the third largest glacier in South America, at $840 \mathrm{~km}^{2}$ in area and $54 \mathrm{~km}$ in length, as measured in 2011 (Skvarca, unpublished data). It has flowed at a rate of $>1600 \mathrm{~m} \mathrm{a}^{-1}$ near the terminus (Skvarca and others, 2003), discharging ice into Brazo Upsala of Lago (lake) Argentino, with an estimated calving flux of 0.47$1.47 \mathrm{~km}^{3} \mathrm{a}^{-1}$ (Naruse and others, 1995) (Fig. 1a). From 1978 to 2000 it underwent rapid retreat (Aniya and Skvarca, 1992; Skvarca and others, 1995, 2002; Naruse and others, 1997; Aniya and others, 2000). During a retreat of $1200 \mathrm{~m}$ from 1990 to 1993, it thinned at an average rate of $11 \mathrm{~m} \mathrm{a}^{-1}$ at the 1993 terminus position (Skvarca and others, 1995).

\section{METHODS}

\subsection{Glacier front position}

We mapped glacier frontal margins from 7 July 2000 to 3 May 2011, using 22 images from the Landsat 7 Enhanced Thematic Mapper Plus (ETM+), band 8, with a processing level of $1 \mathrm{~T}$ (geometrically corrected data) (Table 1). The image resolution was $15 \mathrm{~m}$, and an error associated with the uncertainty of the margin was about $\pm 15 \mathrm{~m}$. The cumulative distance of glacier retreat since July 2000 was measured by taking the northward displacement of the width-averaged calving front position.

\subsection{Ice velocity}

Surface velocity was measured from 7 May 2001 to 3 May 2011 using 16 pairs of Landsat 7 ETM+ images (Table 1). Temporal separations of the image pairs were 97-272 days. We measured the velocity by tracking characteristic surface features such as crevasses and seracs. We defined three velocity targets within four survey sites defined by squares located at 2.7, 4.6, 6.0 and $7.7 \mathrm{~km}$ from the terminus (Fig. 1b). The velocity was calculated from the mean displacement of the three targets at each site. According to the image resolution $(15 \mathrm{~m})$, the error in the target location was $\pm 11 \mathrm{~m}$, corresponding to a velocity uncertainty of $\pm 15-41 \mathrm{ma}^{-1}$. Velocities obtained for the period 7 May14 October 2001 agreed within $8 \%$ with the annual velocity reported for 2000/01 by Skvarca and others (2003). 
Table 1. Satellite images used in this study

\begin{tabular}{|c|c|c|c|c|}
\hline Scene ID & Date & Satellite & Sensor & Resolution \\
\hline LE72310952000189EDC00 & 7 Jul 2000 & \multirow{22}{*}{ Landsat 7} & \multirow{22}{*}{ ETM+ } & \multirow{22}{*}{$15 \mathrm{~m}$} \\
\hline LE72310952000301EDC00 & 27 Oct 2000 & & & \\
\hline LE72310952001127EDC00 & 7 May 2001 & & & \\
\hline LE72310952001287EDC00 & 14 Oct 2001 & & & \\
\hline LE72310952002098EDC00 & 8 Apr 2002 & & & \\
\hline LE72310952004104EDC01 & 13 Apr 2004 & & & \\
\hline LE72310952005058EDC00 & 27 Feb 2005 & & & \\
\hline LE72310952005186ASN00 & 5 Jul 2005 & & & \\
\hline LE72310952005362EDC00 & 28 Dec 2005 & & & \\
\hline LE72310952006029EDC00 & 29 Jan 2006 & & & \\
\hline LE72310952006141EDC00 & 21 May 2006 & & & \\
\hline LE72310952007048EDC00 & 17 Feb 2007 & & & \\
\hline LE72310952007256ASNOO & 13 Sep 2007 & & & \\
\hline LE72310952008019EDC00 & 19 Jan 2008 & & & \\
\hline LE72310952008115EDC01 & 24 Apr 2008 & & & \\
\hline LE72310952008307EDC00 & 2 Nov 2008 & & & \\
\hline LE72310952009133EDC00 & 13 May 2009 & & & \\
\hline LE72310952009341EDC00 & 7 Dec 2009 & & & \\
\hline LE72310952010024EDC00 & 24 Jan 2010 & & & \\
\hline LE72310952010136EDC00 & 16 May 2010 & & & \\
\hline LE72310952010312EDC00 & 8 Nov 2010 & & & \\
\hline LE72310952011123EDC00 & 3 May 2011 & & & \\
\hline ALPSMN044714610 & 26 Nov 2006 & \multirow{4}{*}{ ALOS } & \multirow{4}{*}{ PRISM } & \multirow{4}{*}{$2.5 \mathrm{~m}$} \\
\hline ALPSMB044714665 & 26 Nov 2006 & & & \\
\hline ALPSMN225884610 & 21 Apr 2010 & & & \\
\hline ALPSMB225884665 & 21 Apr 2010 & & & \\
\hline
\end{tabular}

\subsection{Surface elevation}

Changes in ice surface elevation from February 2000 to 26 November 2006, and to 21 April 2010 were measured by differentiating a DEM from the Shuttle Radar Topography Mission (SRTM) and those produced in this study. We produced DEMs for 26 November 2006 and 21 April 2010 by using stereo pairs of satellite images obtained by Panchromatic Remote-sensing Instruments for Stereo Mapping (PRISM) mounted on the Japanese Advanced Land Observing Satellite (ALOS) (Table 1). The nadir- and backward-looking images with a processing level of 1B2 (geometrically corrected data) were distributed with RPC (rational polynomial coefficient) files by the Remote Sensing Technology Centre of Japan (RESTEC). Root-mean-square errors of ALOS PRISM RPC were $0.5-10 \mathrm{~m}$, and typically in the range 1-5 $\mathrm{m}$. The accuracy of the elevation change presented in this paper relies on the quality of the DEMs generated from ALOS PRISM images. We processed the stereo images with the aid of the Leica Photogrammetric Suite (LPS) in the ERDAS IMAGINE workstation. After the generation of DEMs using an automated routine, we edited the elevation data referring to stereoscopic three-dimensional images by LPS. This manual correction process is important in order to improve the accuracy of the DEMs. More details of the DEM generation procedure are given by Lamsal and others (2011). The resolution of the ALOS DEMs was $10 \mathrm{~m}$.

In addition to the ALOS DEMs, we used a DEM based on interferometric synthetic aperture radar measurements during SRTM in February 2000. This dataset covers an area from $60^{\circ} \mathrm{N}$ to $57^{\circ} \mathrm{S}$ (http://eros.usgs.gov/) with a $3^{\prime \prime}$ resolution and a geocoding accuracy of $\pm 12.6 \mathrm{~m}$ (Farr and others, 2007). The resolution of the DEM after a projection on the studied area was $76 \mathrm{~m}$. The ALOS DEMs were interpolated at gridpoints of the SRTM DEM using a bilinear interpolation scheme to compute elevation changes.

Errors in the DEMs were assessed by comparing elevations within $54 \mathrm{~km}^{2}$ rock outcrops surrounding Glaciar Upsala, where elevation changes are negligible. Mean elevation difference and standard deviations were computed for each pair of DEMs as listed in Table 2. The glacier surface has significantly more distinctive features than the neighbouring ice-free terrain, which is favourable for stereo image processing. Thus, we expect smaller errors on the glacier than the values estimated. Systematic errors were removed by correcting the ALOS DEMs for the elevation difference from the SRTM DEM averaged over the compared region. After this correction, random errors represented by the standard deviations were $9.3-11.8 \mathrm{~m}$.

\section{RESULTS}

\subsection{Glacier retreat}

Figure $1 \mathrm{~b}$ shows the migration of the glacier front from 7 July 2000 to 3 May 2011. The front position was relatively stable

Table 2. Deviation of surface elevation from one DEM to the other evaluated over the rock outcrops neighbouring Glaciar Upsala

\begin{tabular}{lcc}
\hline DEMs & Mean difference & Std dev. \\
& $\mathrm{m}$ & $\mathrm{m}$ \\
\hline 2006 ALOS DEM-SRTM DEM & 7.65 & 9.34 \\
2010 ALOS DEM-SRTM DEM & 11.94 & 11.65 \\
2010 ALOS DEM-2006 ALOS DEM & -6.36 & 11.79
\end{tabular}




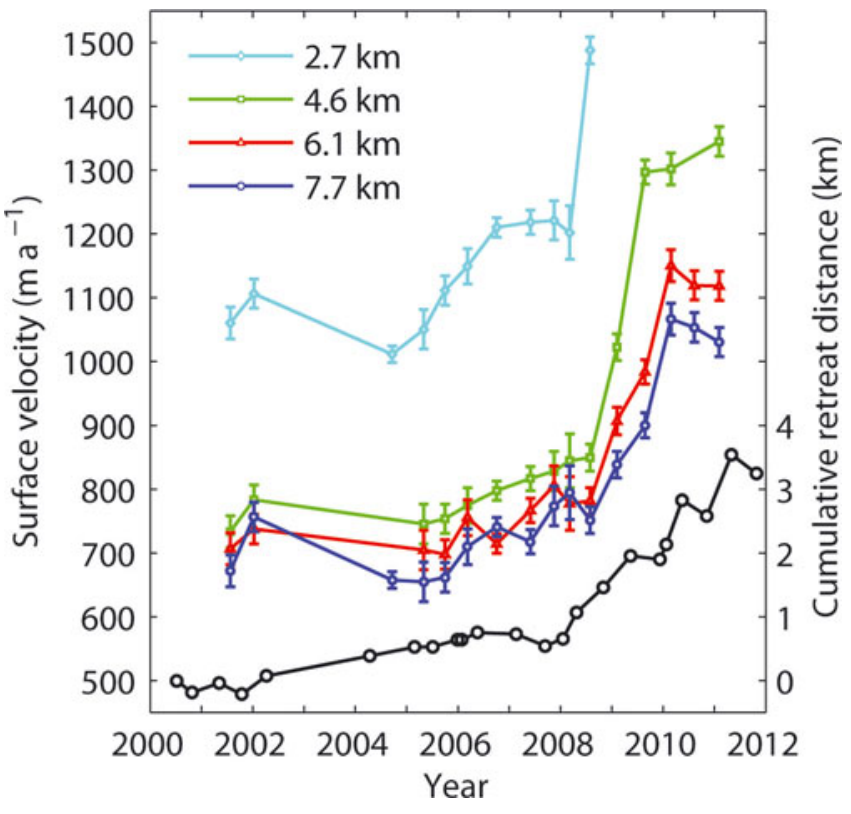

Fig. 2. Ice surface velocities of Glaciar Upsala between 7 May 2001 and 3 May 2011 measured at four locations along the glacier as indicated in Figure $1 \mathrm{~b}$ (coloured lines to the left axis). The error bars were based on the estimated uncertainty in the feature-tracking method. Heavy crevasses at $2.7 \mathrm{~km}$ from the terminus after November 2008 prevented the tracking of surface features. Cumulative retreat distance since 7 July 2000 (black line to the right axis).

until January 2008, particularly near the side margins. From January to November 2008, the eastern half of the glacier retreated by $1540 \mathrm{~m}$ and lost $1.78 \mathrm{~km}^{2}$ of ice. The western side retreated by a similar distance in the following years 2009 and 2010, whereas the front position at the eastern margin remained at approximately the same location over these 2 years. The glacier has retreated progressively, and in May 2011 reached the confluence area, where Glaciar Bertacchi merges with the main stream. The retreat distance from January 2008 to May 2011 was 2890 m.

Cumulative retreat distance since 2000 is shown in Figure 2. The retreat rate was $90 \mathrm{~m} \mathrm{a}^{-1}$ for the period May 2000-January 2008, followed by a sudden increase to a rate of $880 \mathrm{~m} \mathrm{a}^{-1}$ from January 2008 to May 2011. The latest two images, taken in November 2010 and May 2011, give an even larger rate of $2000 \mathrm{ma}^{-1}$. Seasonal signals are recognized in the retreat in 2009 and 2010. After a small advance over the May-December 2009 austral winter, the glacier retreated by $930 \mathrm{~m}$ during the December 2009-May 2010 summer. It advanced again by $250 \mathrm{~m}$ during May-November 2010, followed by a $940 \mathrm{~m}$ retreat from November 2010 to May 2011.

\subsection{Ice velocity change}

The rapid retreat since 2008 was associated with acceleration in the surface velocity (Fig. 2). In 2008, the velocity sharply increased at the four measurement sites. It increased by $24 \%$ at the lowermost site $(2.7 \mathrm{~km})$ from January to April. This change took place within a few months of the onset of rapid retreat and preceded the acceleration at the other sites. At the $4.6 \mathrm{~km}$ site, significant velocity change began after April 2008 and the ice accelerated by $>50 \%$ by May 2009 . Acceleration of a similar magnitude was observed at the upper two sites: $47 \%$ and $43 \%$ at the 6.0 and $7.7 \mathrm{~km}$ sites, respectively. Acceleration ceased at the $4.6 \mathrm{~km}$ site after May
2009, while at the upper sites it lasted until December 2009. Velocities have remained steady since 2010 at the elevated level with respect to the pre-2008 velocity.

\subsection{Surface elevation change}

Surface elevation dropped significantly during the period including the rapid retreat and acceleration (Fig. 3a). From 26 November 2006 to 21 April 2010, ice surface elevation change averaged over the area was $-45.7 \mathrm{~m}\left(-13.4 \mathrm{ma}^{-1}\right)$. The magnitude of the elevation change was greater near the terminus, but decreased down-glacier in the vicinity of the calving front at $<200 \mathrm{~m}$ a.s.l. (Fig. 4). The greatest change was observed at $1200 \mathrm{~m}$ from the calving front, corresponding to a rate of $-39.1 \mathrm{~m} \mathrm{a}^{-1}$. If we assume the elevation change was due exclusively to ice thickness change, $5.90 \mathrm{~km}^{3}\left(1.73 \mathrm{~km}^{3} \mathrm{a}^{-1}\right)$ of ice was lost over the studied $129 \mathrm{~km}^{2}$.

The elevation had been lowering even before the rapid retreat, but at a lower rate. From February 2000 to 26 November 2006, elevation change averaged over the area was $-37.5 \mathrm{~m}\left(-4.7 \mathrm{~m} \mathrm{a}^{-1}\right)$, which is equivalent to ice volume loss of $4.84 \mathrm{~km}^{3}\left(0.61 \mathrm{~km}^{3} \mathrm{a}^{-1}\right)$ over the studied $129 \mathrm{~km}^{2}$. This result indicated that the rate of change has increased by $185 \%$ from $2000-06$ to 2006-10. Within $2000 \mathrm{~m}$ of the calving front, the magnitude of the change was greater near the side margins than in the central part of the glacier (Fig. 3b).

\section{DISCUSSION}

Glaciar Upsala retreated throughout the 20th century (Warren and others, 1995), and several major retreat events have been observed during recent decades. Nevertheless, the event revealed in this study is distinct from those reported in the past. The glacier retreated rapidly from 1981 to 1984 by $1.0 \mathrm{~km}$ at a rate of $150-525 \mathrm{~m} \mathrm{a}^{-1}$, from 1990 to 1993 by $1.2 \mathrm{~km}$ at $400 \mathrm{~m} \mathrm{a}^{-1}$, and from 1996 to 1999 by $1.5 \mathrm{~km}$ at $820 \mathrm{~m} \mathrm{a}^{-1}$ (Aniya and Skvarca, 1992; Skvarca and others, 1995; Naruse and Skvarca, 2000). The $2.9 \mathrm{~km}$ retreat from 2008 to 2011 is greater than these previous observations in terms of magnitude and rate. The sudden transition from a period of relatively stable front position to rapid retreat in 2008 is similar to the observation in the 1980s. After small retreat and advance from 1968 to 1978 (230 $\mathrm{m}$ retreat over the period), the glacier went into a phase of rapid recession interrupted by periods of relatively slow retreat (Naruse and Skvarca, 2000). This transition cannot be attributed to climate change since no significant change has been observed on other glaciers of the Southern Patagonia Icefield (Aniya, 1999). In the case of the transition in 2008, monthly averaged air temperatures at Estancia Cristina $\left(49^{\circ} 58^{\prime} \mathrm{S}, 73^{\circ} 07^{\prime} \mathrm{W}\right.$; $192 \mathrm{~m}$ a.s.I.), located $\sim 12 \mathrm{~km}$ from Glaciar Upsala, were in 2008 and 2009 within the range of annual variation since 2001 (Fig. 5). The mean temperature has slightly increased over the past decade, but is not correlated with the retreat distance (Fig. 2) and does not show a remarkable transition in 2008. We collected this temperature dataset, recorded at hourly intervals, using an Ondotori Thermo Recorder, Model TR-52 (TASHIKA, JAPAN), installed at $2 \mathrm{~m}$ above the rock surface. Naruse and others (1997) argued that the temporally non-uniform recession of Glaciar Upsala was not related to climate variability, but was due to the change in the longitudinal stress exerted by the bedrock near the glacier front. Such a 


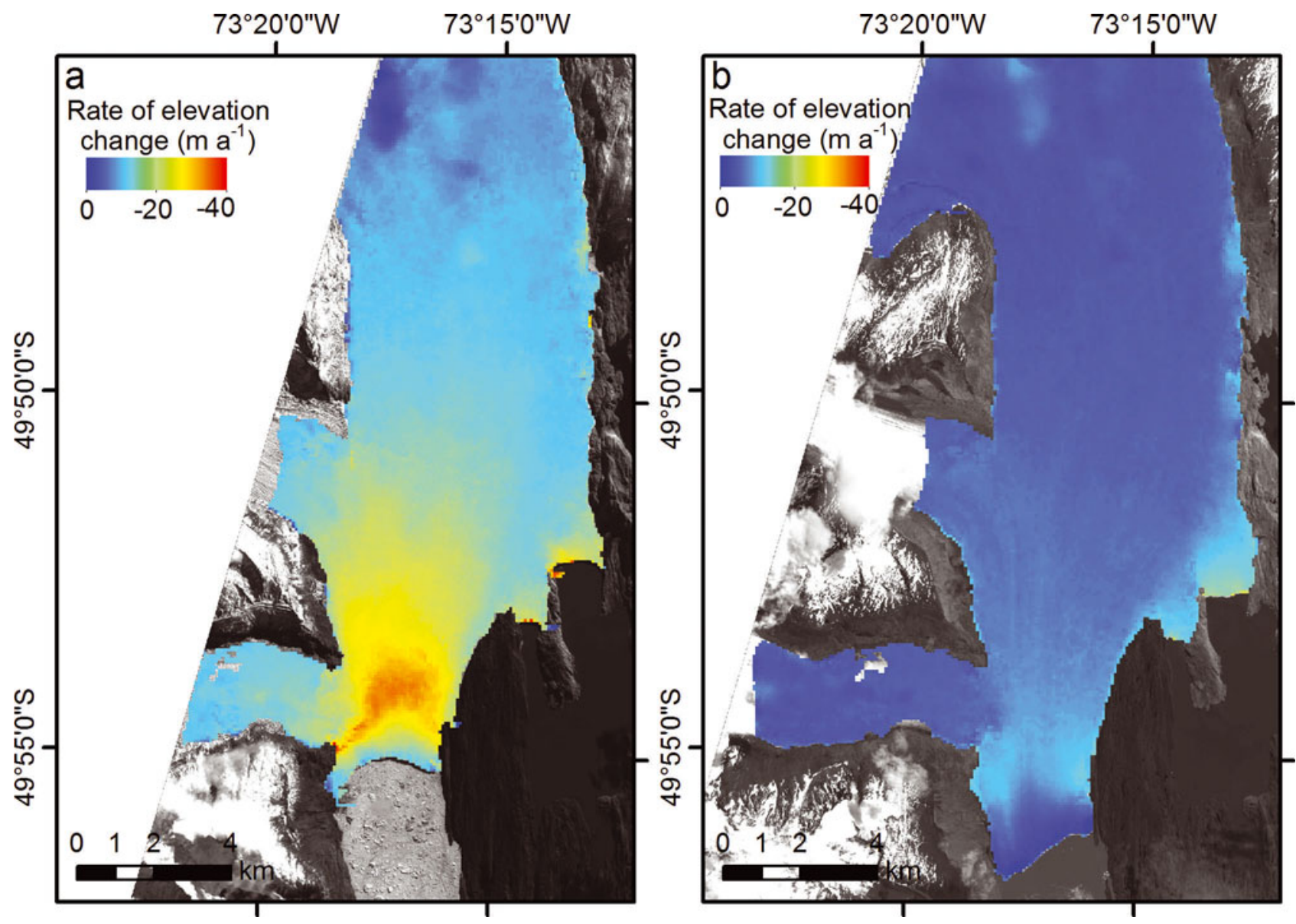

Fig. 3. (a) The rate of surface elevation change over Glaciar Upsala between 26 November 2006 and 21 April 2010. The glacier margin was determined from the satellite image in 2010. (b) Same as (a) for the period February 2000 to 26 November 2006. The glacier margin was determined from the satellite image in 2006.

change takes place when the terminus retreats over a bedrock rise into deeper water along a reversed bed slope. Numerical studies also indicate that previously observed frontal variations of calving glaciers are primarily controlled by bedrock undulations (Vieli and others, 2002; Nick and others, 2009). It is also likely that the non-uniform retreat

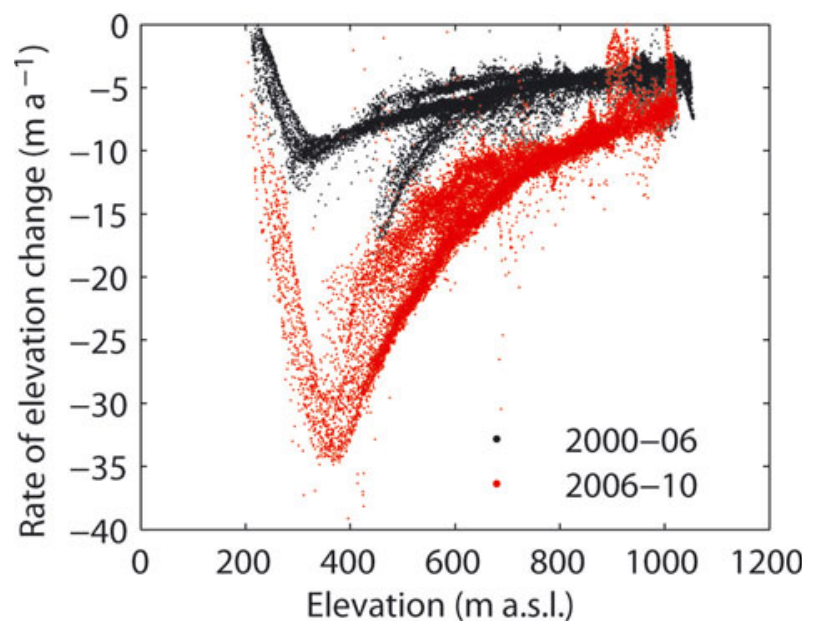

Fig. 4. The rate of surface elevation change over the regions shown in Figure $3 \mathrm{a}$ and $\mathrm{b}$. The black and red dots represent elevation changes over the periods 2000-06 and 2006-10 respectively, evaluated at the gridpoints of the SRTM DEM. The elevation in the abscissa corresponds to the values in 2000 and 2006, respectively. across the glacier, i.e. initial retreat near the eastern margin from January to November 2008, followed by the larger ice loss in the middle and western side of the glacier, was due to a spatial pattern of the bedrock elevation. Similar irregular patterns of the calving front profile have been observed at Glaciar Upsala over the course of its retreat (Aniya and Skvarca, 1992; Skvarca and others, 2002).

In Patagonia, high-frequency ice velocity measurements are very rare, and acceleration associated with glacier

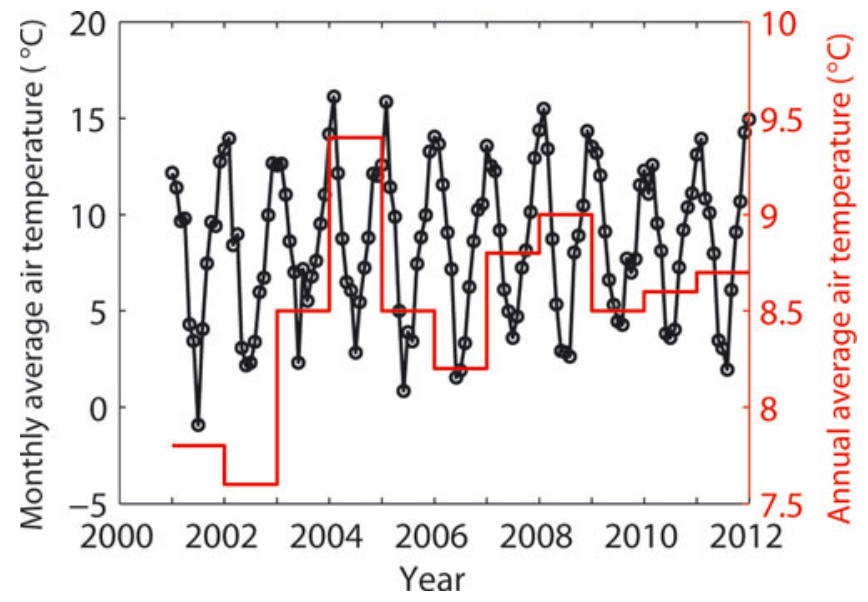

Fig. 5. Monthly average air temperatures from 2001 to 2012 at Estancia Cristina, located $\sim 12 \mathrm{~km}$ from Glaciar Upsala. 


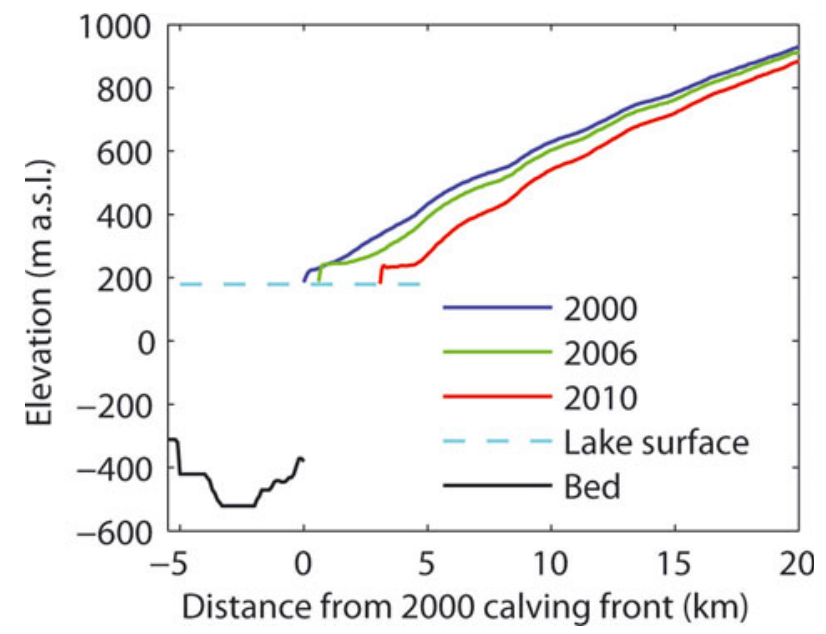

Fig. 6. Glacier surface elevation along the white line in Figure 1b. The black line indicates the lake bed elevation reported by Skvarca and others (2002).

retreat has never been resolved in the past. Our observations confirm the vital role of changing glacier dynamics in the evolution of calving glaciers in Patagonia and in the mass change of the icefields as suggested by Rignot and others (2003). The close agreement between the onsets of retreat and acceleration is consistent with the hypothesis that the speed-up was triggered by back-stress reduction due to the detachment of the ice front from a bedrock rise. According to the bathymetry of Brazo Upsala (Skvarca and others, 2002 ), the lake floor inclines $\sim 3^{\circ}$ down-glacier from the 2000 ice front position to the $3 \mathrm{~km}$ lower reaches (Fig. 6). The bathymetry is available only up to the 2000 front position, but the lake is plausibly deepening up-glacier as an overdeepening is expected at the confluence area, where Glaciar Bertacchi merges from the west. Figure 7 shows details of speed-up propagation upstream and resulting changes in the flow regime. The speed-up began near the glacier front and subsequently propagated up-glacier, reaching a point $7.7 \mathrm{~km}$ behind the front within 1 year. Accordingly, the velocity gradient along the glacier first increased between the 2.7 and $4.6 \mathrm{~km}$ sites and later in the upper reaches. Longitudinal strain rate between the 2.7 and $4.6 \mathrm{~km}$ sites increased by $79 \%$ (from $0.19 \mathrm{a}^{-1}$ to $0.34 \mathrm{a}^{-1}$ ) after April 2008, whereas the strain rate between the 4.6 and $7.7 \mathrm{~km}$ sites increased by $233 \%$ (from $0.03 \mathrm{a}^{-1}$ to $0.10 \mathrm{a}^{-1}$ ) from April-November 2008 to November 2010-May 2011. Thus, ice was significantly thinning as a result of compressive vertical straining during these periods. These observations suggest that the initial acceleration results in ice thinning near the terminus, which steepens the ice surface and increases the driving stress, leading to acceleration in the upper reaches (Nick and others, 2009). In fact, glacier surface inclination over the lower $10 \mathrm{~km}$ increased from $2.50^{\circ}$ in 2006 to $2.69^{\circ}$ in 2010 , whereas it changed little from 2000 to 2006 (Fig. 6) Moreover, the thinning also enhances basal ice motion as the effective pressure decreases at the bed (Sugiyama and others, 2011).

Average surface elevation change of $-11.1 \mathrm{ma}^{-1}$ was measured previously at Glaciar Upsala during the 1990-93 retreat (Skvarca and others, 1995; Naruse and others, 1997). Because this measurement was performed at $1-2 \mathrm{~km}$ from the terminus where the largest change was expected, the rate of $-13.4 \mathrm{~m} \mathrm{a}^{-1}$ from 2006 to 2010 as a mean for the region

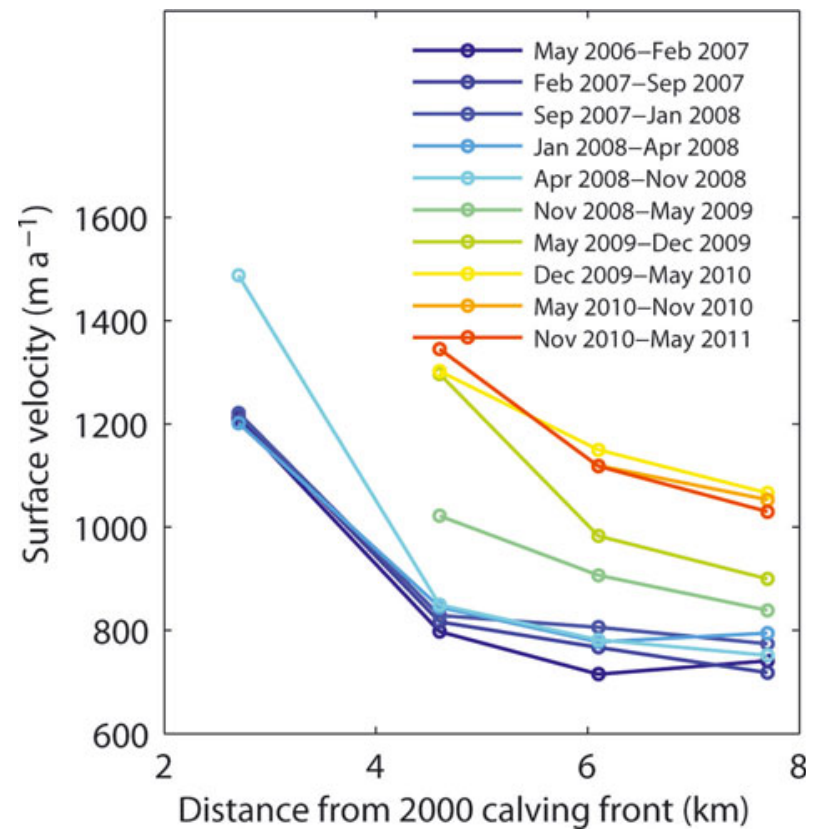

Fig. 7. Ice surface velocity measured from 2006 to 2011 at the locations indicated in Figure $1 \mathrm{~b}$.

extending over $16 \mathrm{~km}$ from the terminus is substantially larger. Surface ablation at the glacier front was estimated to be $14 \pm 2 \mathrm{~m} \mathrm{a}^{-1}$, with annual variations of $\pm 2 \mathrm{ma}^{-1}$ (Naruse and others, 1997). Thus, mass-balance variation related to climate change cannot explain the observed elevation change. It is most likely that ice is thinning under the influence of the changing longitudinal strain rate caused by the velocity change (e.g. Thomas and others, 2003). A clear indication of the dynamically controlled ice thickness change was the elevation change peaking at $1.4 \mathrm{~km}$ from the 2011 front position (Figs 3a and 6). Presumably, the effect of the longitudinal velocity gradient, i.e. longitudinal strain rate, on the ice thickness change was greatest at this location. The reduction in elevation change near the terminus also suggested that part of the ice thinning might have been compensated for by uplift due to flotation. The possibility of a floating terminus has been pointed out previously, based on the bathymetry of the lake and height of the calving cliff (Naruse and Skvarca, 2000). The height of the ice cliff at the calving front was $51 \mathrm{~m}$ as measured with the 2010 DEM, which indicates that $516 \mathrm{~m}$ water depth is sufficient for terminus flotation. This condition is met if the lake floor slopes up-glacier from the 2000 terminus position.

Despite the difference between calving into fresh- or tidewater, our observations at Glaciar Upsala have many similarities with rapid changes reported in outlet glaciers of the Greenland ice sheet. Many tidewater calving glaciers in Greenland have shown a sudden transition from a quiescent phase to rapid retreat, thinning and acceleration during the last decade (e.g. Rignot and Kanagaratnam, 2006; McFadden and others, 2011). One example is Helheim Glacier, the fastest-flowing outlet glacier along the eastern margin of the ice sheet (Rignot and others, 2004). From 2001 to 2005, this glacier retreated at a rate of $1.8 \mathrm{~km} \mathrm{a}^{-1}$, accelerated by $26 \%$ and thinned at a rate of $27 \mathrm{~m} \mathrm{a}^{-1}$ within $5 \mathrm{~km}$ of the terminus (Howat and others, 2008). Another example is Columbia Glacier, a fast-flowing outlet glacier in Alaska. Columbia Glacier began its rapid retreat in 1982, and the greatest retreat occurred in $1993\left(1.2 \mathrm{~km} \mathrm{a}^{-1}\right)$. Velocity at the terminus 
increased from $5 \mathrm{~m} \mathrm{~d}^{-1}$ to $>27 \mathrm{~m} \mathrm{~d}^{-1}$ between 1980 and 2001. During the acceleration and retreat, the glacier thinned by $>320 \mathrm{~m}$ from 1982 to 2001 (O'Neel and others, 2005). These values are comparable to those of Glaciar Upsala observed after 2008. Thus, collecting data from other calving glaciers and understanding the mechanism of their dynamic behaviour are of crucial importance for evaluating the current and future ice mass change in Patagonia.

\section{CONCLUSIONS}

We analysed satellite images acquired during the period 2000-11 to quantify recent changes in front position, ice speed and thickness of Glaciar Upsala, one of the largest freshwater calving glaciers in Patagonia. The results showed a clear transition in 2008 from a period of relatively stable front position $(670 \mathrm{~m}$ retreat from 2000 to 2008) to rapid recession (2890 m retreat from 2008 to 2011). The retreat phase continues in 2011. The rate of retreat in 2008-10 was $880 \mathrm{~m} \mathrm{a}^{-1}$, which is about ten times larger than in 2000-08, resulting in one of the most significant retreat events observed at this glacier. The rapid retreat was associated with ice flow acceleration, initiated near the calving front and propagated up-glacier. The glacier sped up by $20-50 \%$ in the region extending $7.7 \mathrm{~km}$ from the calving front. We also observed substantial ice thinning from 2006 to 2010, at a maximum rate of $39 \mathrm{~m} \mathrm{a}^{-1}$ near the terminus, and a mean of $13.4 \mathrm{~m} \mathrm{a}^{-1}$ over the area extending $16 \mathrm{~km}$ from the terminus. The rate of ice mass loss during this period was $1.73 \mathrm{~km}^{3} \mathrm{a}^{-1}$, i.e. a total of $5.90 \mathrm{~km}^{3}$ during the 3.4 years within the analysed $129 \mathrm{~km}^{2}$. Our data indicate that the magnitude and the rate of glacier change at Glaciar Upsala are similar to those reported in large tidewater glaciers in Greenland. It is thus crucial to study the variations of other calving glaciers in order to quantify the ice mass loss of the Patagonia Icefields.

\section{ACKNOWLEDGEMENTS}

Landsat images were downloaded from http://earthexplorer. usgs.gov/ and SRTM DEM from http://eros.usgs.gov/. We thank T. Yamanokuchi and T. Fukuda for help with the satellite data analysis. The manuscript was improved by the comments of R. Naruse and M. Aniya. This research was funded by the Japanese Ministry of Education, Science, Sports and Culture through Grant-in-Aid 23403006 (2011-14) and the Global COE Program (Establishment of Center for Integrated Field Environmental Science). Financial support was also provided by Dirección Nacional del Antártico-Instituto Antártico Argentino through the project Ice-Climate Interaction and Glacier Dynamics on Antarctic Peninsula and Southern Patagonia. We thank N.E. Barrand and an anonymous reviewer for valuable comments, and the scientific editor, Tavi Murray, for handling the paper.

\section{REFERENCES}

Amundson JM, Fahnestock M, Truffer M, Brown J, Lüthi MP and Motyka RJ (2010) Ice mélange dynamics and implications for terminus stability, Jakobshavn Isbræ, Greenland. J. Geophys. Res., 115(F1), F01005 (doi: 10.1029/2009JF001405)

Aniya M (1999) Recent glacier variations of the Hielo Patagónicos, South America, and their contribution to sea-level change. Arct. Antarct. Alp. Res., 31(2), 165-173
Aniya M and Skvarca P (1992) Characteristics and variations of Upsala and Moreno glaciers, southern Patagonia. Bull. Glacier Res., 10, 39-53

Aniya M, Dhakal AS, Park S and Naruse R (2000) Variations of Patagonian glaciers, South America, using RADARSAT and Landsat images. Can. J. Remote Sens., 26(6), 501-511

Chen JL, Wilson CR, Tapley BD, Blankenship DD and Ivins ER (2007) Patagonia Icefield melting observed by Gravity Recovery and Climate Experiment (GRACE). Geophys. Res. Lett., 43(22), L22501 (doi: 10.1029/2007GL031871)

Farr TG and 17 others (2007) The Shuttle Radar Topography Mission. Rev. Geophys., 45(2), RG2004 (doi: 10.1029/2005RG000183)

Howat IM, Joughin I, Tulaczyk S and Gogineni S (2005) Rapid retreat and acceleration of Helheim Glacier, east Greenland. Geophys. Res. Lett., 32(22), L22502 (doi: 10.1029/2005GL024737)

Howat IM, Joughin IR and Scambos TA (2007) Rapid changes in ice discharge from Greenland outlet glaciers. Science, 315(5818), 1559-1561 (doi: 10.1126/science.1138478)

Howat IM, Smith BE, Joughin I and Scambos TA (2008) Rates of southeast Greenland ice volume loss from combined ICESat and ASTER observations. Geophys. Res. Lett., 35(17), L17505 (doi: 10.1029/2008GL034496)

Howat IM, Box JE, Ahn Y, Herrington A and McFadden EM (2010) Seasonal variability in the dynamics of marine-terminating outlet glaciers in Greenland. J. Glaciol., 56(198), 601-613 (doi: 10.3189/002214310793146232)

Iken A and Bindschadler RA (1986) Combined measurements of subglacial water pressure and surface velocity of Findelengletscher, Switzerland: conclusions about drainage system and sliding mechanism. J. Glaciol., 32(110), 101-119

Iken A and Truffer M (1997) The relationship between subglacial water pressure and velocity of Findelengletscher, Switzerland, during its advance and retreat. J. Glaciol., 43(144), 328-338

Jacob T, Wahr J, Pfeffer WT and Swenson S (2012) Recent contributions of glaciers and ice caps to sea level rise. Nature, 482(7386), 514-518 (doi: 10.1038/nature10847)

Joughin I, Abdalati W and Fahnestock MA (2004) Large fluctuations in speed on Greenland's Jakobshavn Isbræ glacier. Nature, 432(7017), 608-610 (doi: 10.1038/nature03130)

Joughin I and 8 others (2008) Ice-front variation and tidewater behavior on Helheim and Kangerdlugssuaq Glaciers, Greenland. J. Geophys. Res., 113(F1), F01004 (doi: 10.1029/2007JF000837)

Lamsal D, Sawagaki T and Watanabe T (2011) Digital terrain modelling using Corona and ALOS PRISM data to investigate the distal part of Imja Glacier, Khumbu Himal, Nepal. J. Mt Sci. [China], 8(3), 390-402 (doi: 10.1007/s11629-011-2064-0)

McFadden EM, Howat IM, Joughin I, Smith BE and Ahn Y (2011) Changes in the dynamics of marine terminating outlet glaciers in west Greenland (2000-2009). J. Geophys. Res., 116(F2), F02022 (doi: 10.1029/2010JF001757)

Naruse R and Skvarca P (2000) Dynamic features of thinning and retreating Glaciar Upsala, a lacustrine calving glacier in southern Patagonia. Arct. Antarct. Alp. Res., 32(4), 485-491

Naruse R, Aniya M, Skvarca P and Casassa G (1995) Recent variations of calving glaciers in Patagonia, South America, revealed by ground surveys, satellite-data analyses and numerical experiments. Ann. Glaciol., 21, 297-303

Naruse R, Skvarca P and Takeuchi Y (1997) Thinning and retreat of Glaciar Upsala, and an estimate of annual ablation changes in southern Patagonia. Ann. Glaciol., 24, 38-42

Nick FM, Vieli A, Howat IM and Joughin I (2009) Large-scale changes in Greenland outlet glacier dynamics triggered at the terminus. Nature Geosci., 2(2), 110-114 (doi: 10.1038/ ngeo394)

O'Neel S, Pfeffer WT, Krimmel R and Meier M (2005) Evolving force balance at Columbia Glacier, Alaska, during its rapid retreat. J. Geophys. Res., 110(F3), F03012 (doi: 10.1029/ 2005JF000292)

Parizek BR and Alley RB (2004) Implications of increased Greenland surface melt under global-warming scenarios: ice-sheet 
simulations. Quat. Sci. Rev., 23(9-10), 1013-1027 (doi: 10.1016/j.quascirev.2003.12.024)

Pritchard HD, Arthern RJ, Vaughan DG and Edwards LA (2009) Extensive dynamic thinning on the margins of the Greenland and Antarctic ice sheets. Nature, 461(7266), 971-975 (doi: 10.1038/nature08471)

Rignot E and Kanagaratnam P (2006) Changes in the velocity structure of the Greenland Ice Sheet. Science, 311(5673), 986-990 (doi: 10.1126/science.1121381)

Rignot E, Rivera A and Casassa G (2003) Contribution of the Patagonian icefields of South America to sea level rise. Science, 302(5644), 434-437 (doi: 10.1126/science.1087393)

Rignot E, Braaten D, Gogineni P, Krabill WB and McConnell JR (2004) Rapid ice discharge from southeast Greenland glaciers. Geophys. Res. Lett., 31(10), L10401 (doi: 10.1029/ 2004GL019474)

Rivera A, Benham T, Casassa G, Bamber J and Dowdeswell JA (2007) Ice elevation and areal changes of glaciers from the Northern Patagonia Icefield, Chile. Global Planet. Change, 59(1-4), 126-137 (doi: 10.1016/j.gloplacha.2006.11.037)

Skvarca P, Satow K, Naruse R and Leiva JC (1995) Recent thinning, retreat and flow of Upsala Glacier, Patagonia. Bull. Glacier Res., 13, 11-20

Skvarca P, De Angelis H, Naruse R, Warren CR and Aniya M (2002) Calving rates in fresh water: new data from southern Patagonia. Ann. Glaciol., 34, 379-384 (doi: 10.3189/ 172756402781817806)

Skvarca P, Raup B and De Angelis H (2003) Recent behaviour of Glaciar Upsala, a fast-flowing calving glacier in Lago Argentino, southern Patagonia. Ann. Glaciol., 36, 184-188 (doi: 10.3189/ 172756403781816202)
Skvarca P, Marinsek S and Aniya M (2010) Documenting 23 years of areal loss of Hielo Patagónico Sur, recent climate data and potential impact on Río Santa Cruz water discharge. In Abstracts. International Glaciological Conference. Ice and climate change: a view from the South. Centro de Estudios Científicos, Valdivia, Chile, 82

Sugiyama $S$ and 7 others (2011) Ice speed of a calving glacier modulated by small fluctuations in basal water pressure. Nature Geosci., 4(9), 597-600 (doi: 10.1038/ngeo1218)

Thomas RH (2004) Force-perturbation analysis of recent thinning and acceleration of Jakobshavn Isbræ, Greenland. J. Glaciol., 50(168), 57-66 (doi: 10.3189/172756504781830321)

Thomas RH, Abdalati W, Frederick E, Krabill WB, Manizade S and Steffen K (2003) Investigation of surface melting and dynamic thinning on Jakobshavn Isbræ, Greenland. J. Glaciol., 49(165), 231-239 (doi: 10.3189/172756503781830764)

Vieli A, Jania J and Kolondra L (2002) The retreat of a tidewater glacier: observations and model calculations on Hansbreen, Spitsbergen. J. Glaciol., 48(163), 592-600 (doi: 10.3189/ 172756502781831089)

Warren CR, Greene DR and Glasser NF (1995) Glaciar Upsala, Patagonia: rapid calving retreat in fresh water. Ann. Glaciol., 21, 311-316

Willis MJ, Melkonian AK, Pritchard ME and Rivera A (2012) Ice loss from the Southern Patagonian Ice Field, South America, between 2000 and 2012. Geophys. Res. Lett., 39(16), L17501 (doi: 10.1029/2012GL053136)

Zwally HJ, Abdalati W, Herring T, Larson K, Saba J and Steffen K (2002) Surface melt-induced acceleration of Greenland icesheet flow. Science, 297(5579), 218-222 (doi: 10.1126/ science.1072708) 